\title{
sciendo
}

CIVIL AND ENVIRONMENTAL ENGINEERING REPORTS

E-ISSN 2450-8594

CEER 2019; 29 (3): 228-240

DOI: $10.2478 /$ ceer-2019-0038

Original Research Article

\section{FLEXURAL BEHAVIOUR OF A COLD-FORMED STEEL- CONCRETE COMPOSITE BEAM WITH CHANNEL TYPE SHEAR CONNECTOR - AN EXPERIMENTAL AND ANALYTICAL STUDY}

\author{
Sangeetha PALANIVELU ${ }^{1}$ \\ SSN College of Engineering, Chennai, India
}

\begin{abstract}
Steel-concrete composite structures are widely used in the current construction of bridges and multi-storey buildings. The effect of shear connectors in a cold-formed steelcomposite beam was studied under flexure. The number of channel connectors in the specimen was varied and the same was compared with a specimen without shear connectors. The performance and failure of cold-formed steel-composite beams were then studied. The presence of shear connectors in the tension zone prevents the formation of cracks which are the major cause of failure in a beam subjected to bending. The loadcarrying capacity is greater in a composite beam and an increase in the number of channel connectors from one to five increases the load-carrying capacity by $60 \%$ as compared to a specimen without a connector. A composite beam with five connectors is more ductile, with a ductility factor of 14 . The Composite beams were also analysed using the finite element software ANSYS and were found to have good agreement with the experimental results.
\end{abstract}

Keywords: Cold-formed steel, Composite beam, channel connectors, load - slip, load - strain, ANSYS

${ }^{1}$ Corresponding author: SSN College of Engineering, Rajiv Gandhi Salai, Kalavakkam, Chennai 603110, Tamil Nadu, India, e-mail: sangeethap@ssn.edu.in 


\section{INTRODUCTION}

The use of steel in the construction industry is relatively low in India when compared with many other countries. The reason behind this is primarily a lack of steel as a construction material. Cold-formed steel sections are lighter in weight and more economical in medium-scale construction with lighter loads, whereas, cold-formed steel sections encased in concrete are more effective and economical in major civil engineering structures like bridges and high-rise buildings. Kottiswaran N \& Sundarajan R [1], have conducted experimental investigations into the behaviour of steel-concrete composite beams and concluded that they are more vulnerable to deformity than conventional reinforced concrete beams designed for the same tensile force. Eray Baran \& Cem Topkaya [2], described an experimental study on European channel shear connectors and new equations were developed for the ultimate resistance of channel shear connectors. Adil Dar $M$ et.al [3], presented a novel method for improving the strength and stiffness of cold-formed steel-composite beams and compared the results with the performance of beams with a hot rolled section. Manikandan P [4], carried out a parametric study using finite element software on a cold-formed steel built-up beam under two-point loading and compared the results with published experimental results and codal provisions. Nadim Wehbe et.al [5], performed an experimental investigation on a composite beam under gravity loading. Their results indicated that cold-formed steel-composite beams are both feasible and accurate. Anis Saggaff et.al [6], studied the composite action of a cold-formed steel section with bolted shear connectors of $16 \mathrm{~mm}$ diameter, which yielded better strength and moment carrying capacity. Sangeetha P et.al [7-10], studied the composite action of a sandwich beam and composite space truss under ultimate loading conditions. The conclusions drawn from their study were that full composite action in composite structures is achieved by using proper shear connectors. In this paper, an attempt was made to study the flexural behaviour of cold-formed steel-concrete composite beams with varying numbers of channel connectors.

\section{EXPERIMENTAL STUDY}

Six composite beams were fabricated with cold-formed steel channel sections of size $150 \times 50 \times 15 \times 1 \mathrm{~mm}$ with varying numbers of channel connectors, $0,1,2$, 3 , 4, and 5. The dimensions of the channel section, being $40 \times 40 \times 40 \times 20 \mathrm{~mm}$, were welded at a spacing of $500 \mathrm{~mm}, 340 \mathrm{~mm}, 300 \mathrm{~mm}, 230 \mathrm{~mm}$, and $200 \mathrm{~mm}$ for the beams with $1,2,3,4$, and 5 connectors, respectively. The dimensions of the cold-formed steel sections with channel connectors are shown in Figure 1. 
Table 1 gives the specifications and properties of the materials. The beams after fabrication are shown in Figure 2. All the channel connectors were fixed with strain gauge with a gauge length of $20 \mathrm{~mm}$ in order to measure the strain in the connectors under flexure. The cold-formed steel section was filled with M25 grade concrete. Figure 3 shows the channel connectors with a strain gauge and after placing of concrete. The curing of the beams was done using the curing agent Sethard S100, applied to the surface of the concrete after it reached the initial setting time.
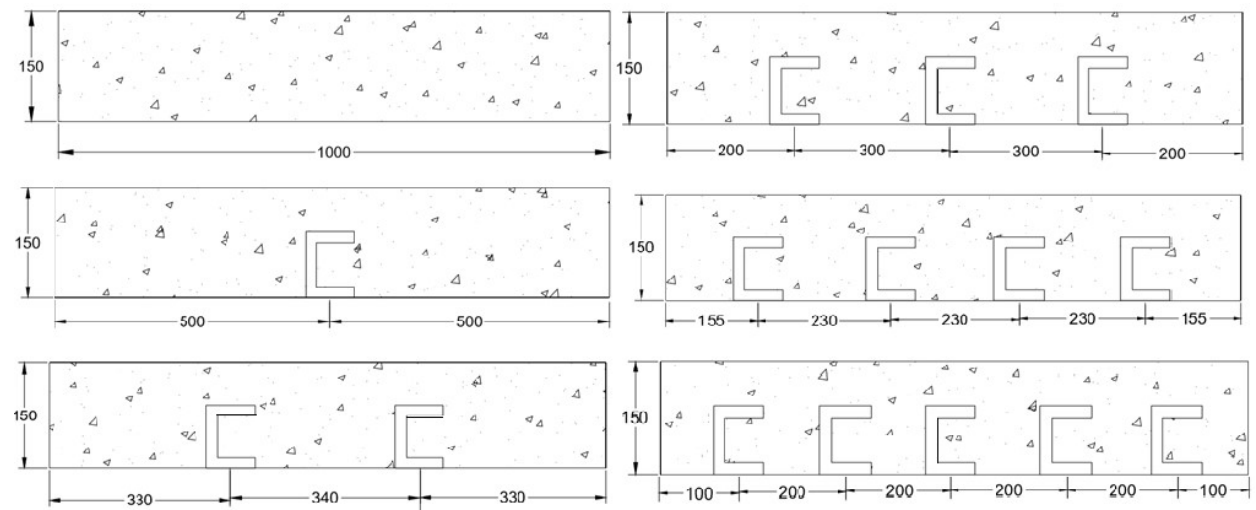

Fig. 1. Detailed dimension of the composite beams with channel connectors

Table 1. Specification of the samples and their properties

\begin{tabular}{|c|c|c|c|c|c|c|}
\hline $\begin{array}{l}\text { Sl. } \\
\text { No }\end{array}$ & $\begin{array}{l}\text { Sample } \\
\text { Name }\end{array}$ & $\begin{array}{l}\text { Dimensions of } \\
\text { the Channel } \\
\text { section } \\
(\mathrm{mm})\end{array}$ & $\begin{array}{l}\text { Dimensions } \\
\text { of the } \\
\text { Channel } \\
\text { shear } \\
\text { connector } \\
(\mathrm{mm})\end{array}$ & $\begin{array}{l}\text { Number of } \\
\text { Connectors }\end{array}$ & $\begin{array}{c}E_{\mathrm{s}} \\
\left(\mathrm{N} / \mathrm{mm}^{2}\right)\end{array}$ & $\begin{array}{c}E_{c} \\
\left(\mathrm{~N} / \mathrm{mm}^{2}\right)\end{array}$ \\
\hline 1 & $\begin{array}{l}\mathrm{CB}-\mathrm{MS} \\
-0 \mathrm{CC}\end{array}$ & \multirow{6}{*}{$\begin{array}{c}150 \times 15 \times 1 \\
\text { with } 15 \mathrm{~mm} \text { lip }\end{array}$} & \multirow{6}{*}{$\begin{array}{l}40 \times 40 \times 2 \\
\text { with } 40 \\
\text { mm length }\end{array}$} & 0 & \multirow{6}{*}{$2 \times 10^{5}$} & \multirow{6}{*}{25000} \\
\hline 2 & $\begin{array}{l}\mathrm{CB}-\mathrm{MS} \\
-1 \mathrm{CC}\end{array}$ & & & 1 & & \\
\hline 3 & $\begin{array}{l}\mathrm{CB}-\mathrm{MS} \\
-2 \mathrm{CC}\end{array}$ & & & 2 & & \\
\hline 4 & $\begin{array}{l}\mathrm{CB}-\mathrm{MS} \\
-3 \mathrm{CC}\end{array}$ & & & 3 & & \\
\hline 5 & $\begin{array}{l}\mathrm{CB}-\mathrm{MS} \\
-4 \mathrm{CC}\end{array}$ & & & 4 & & \\
\hline 6 & $\begin{array}{l}\mathrm{CB}-\mathrm{MS} \\
-5 \mathrm{CC}\end{array}$ & & & 5 & & \\
\hline
\end{tabular}




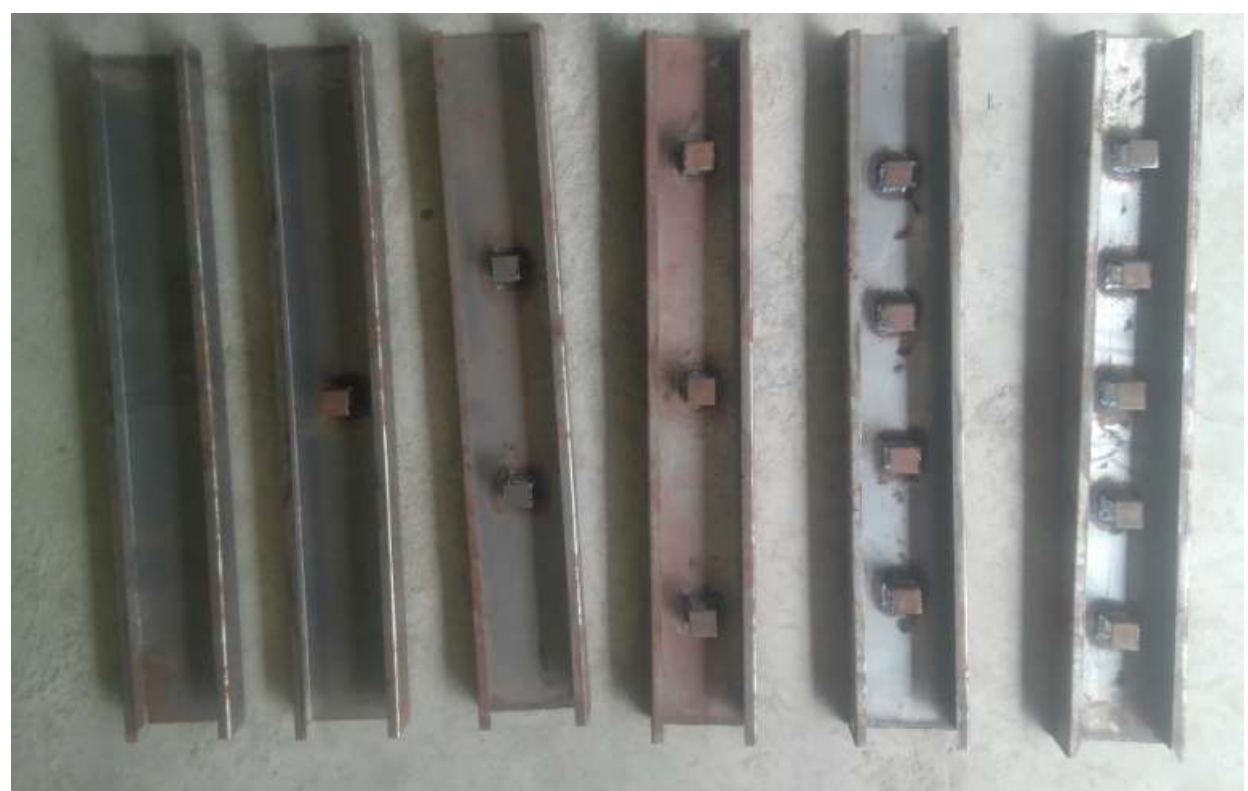

Fig. 2. Samples after fabrication
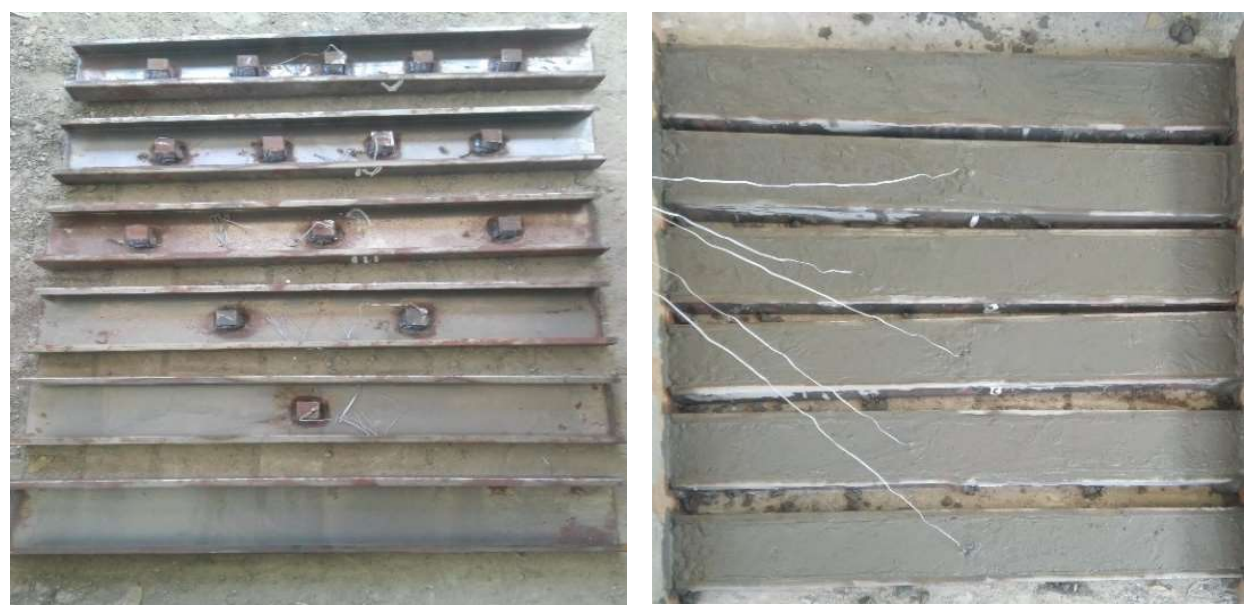

Fig. 3. Samples with a strain gauge on the channel shear connectors

All the samples were tested to failure by gradually applying load at an interval of $2.5 \mathrm{kN}$ using a universal testing machine of capacity $600 \mathrm{kN}$. Figure 4 shows the composite beam under loading. The cracks and mode of failure were observed and recorded. 


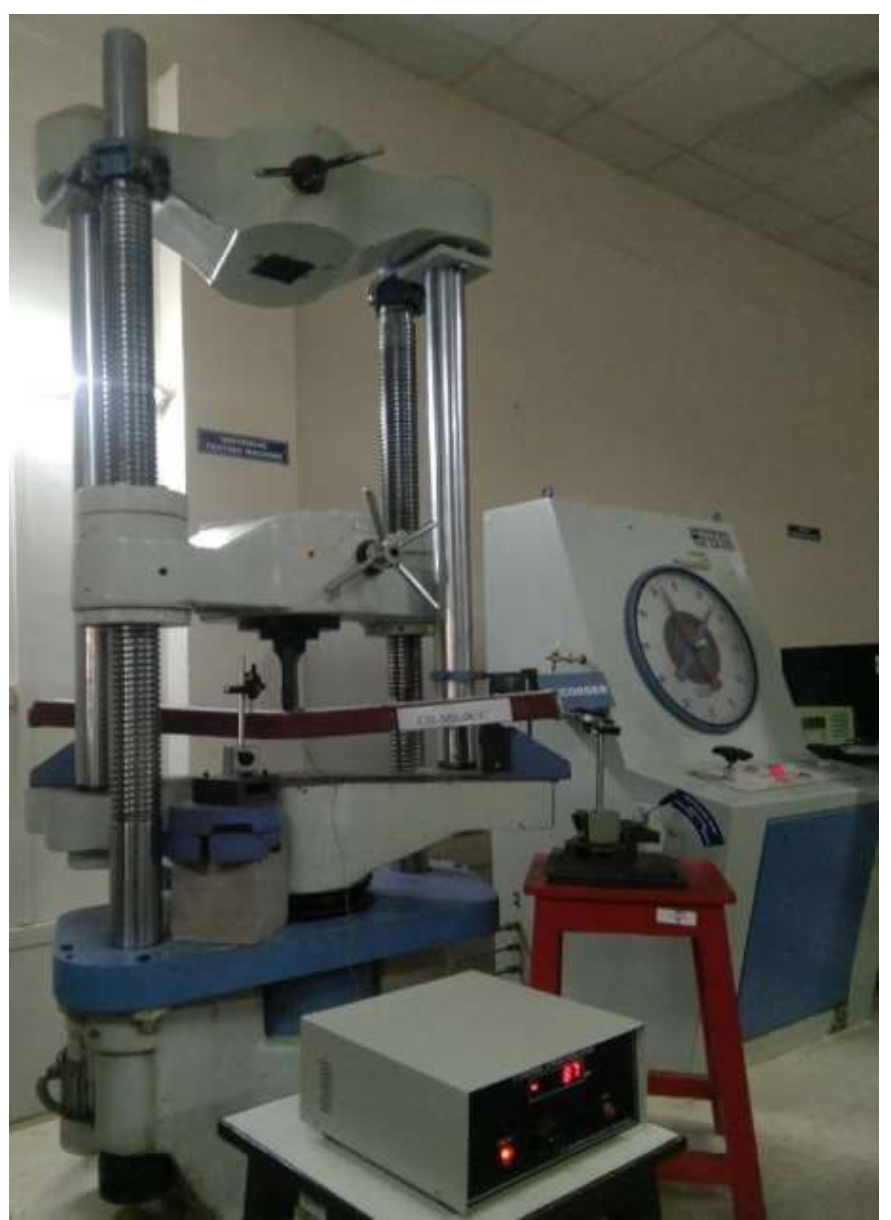

Fig. 4. Cold-formed steel-composite beam under testing using UTM

\section{RESULTS AND DISCUSSION}

\subsection{Mode of Failure}

All the samples failed due to yielding of the cold-formed steel at the bottom of the composite beam. The slippage between the steel and concrete was also observed using dial gauges with the value being lower for the samples with more shear connectors. Cracks appeared on the top of the concrete under the loading point. Further increase in the load encouraged the formation of multiple cracks at closer intervals. Cracks were also observed at the location of the shear connectors, which implies failure of the shear connectors in the tension zone. Figure 5 shows the composite beam before and after testing. 

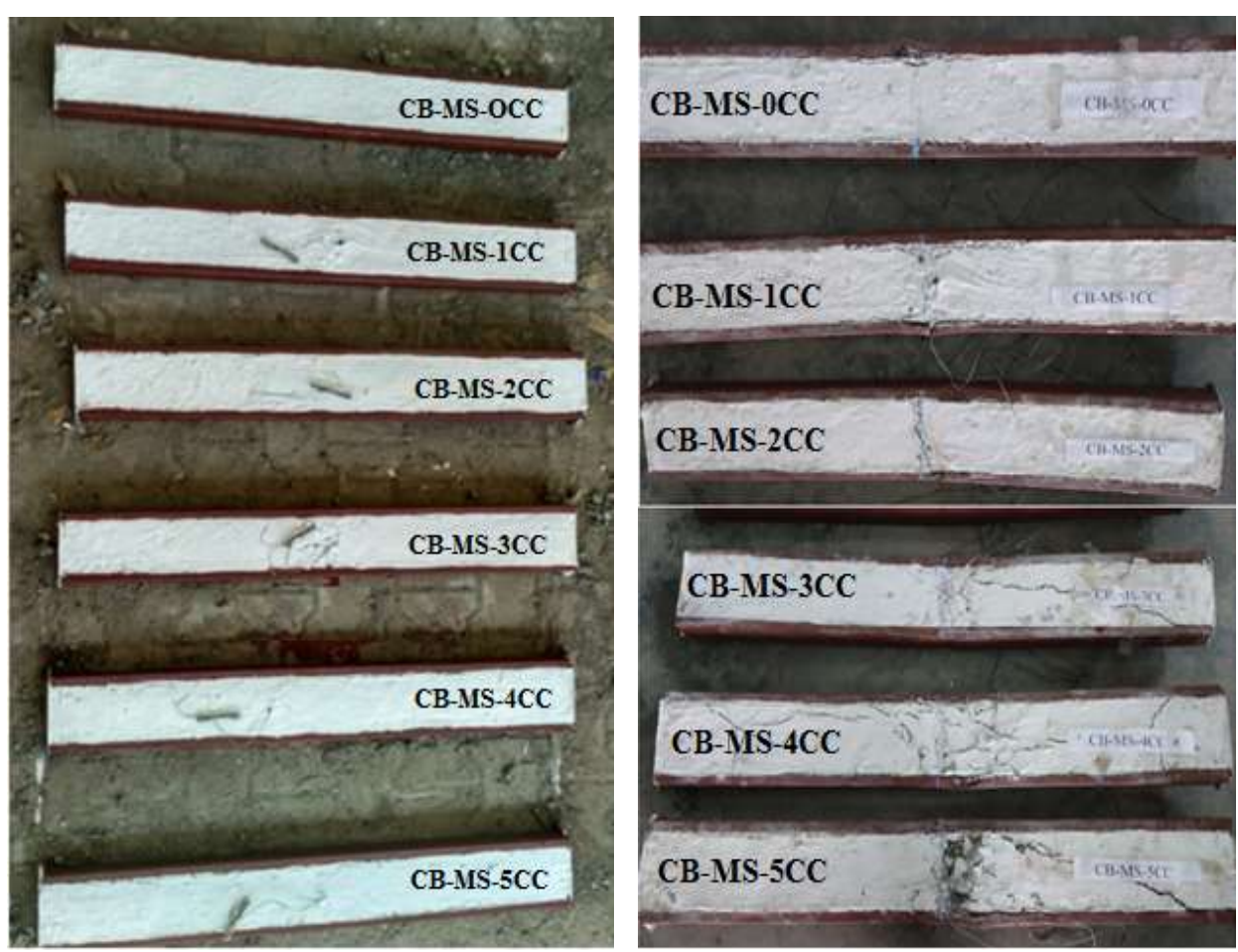

Fig. 5. Cold-formed steel-composite beams before and after testing

\subsection{Load - deflection behaviour}

The load-deflection behaviour for the cold-formed composite beam is shown in Figure 6. From the graph, it can be observed that all the curves are linear up to the first crack. In the post cracking stage, the behaviour of the load-deflection is uniform for all the specimens, with a lesser slope. This slope is found to be less for the sample with five channel connectors than those without connectors. The energy absorption capacity, being the area under the load-deflection curve, is higher for the composite beam with five channel connectors. Improved ductile behaviour is observed for the samples with five channel connectors. 


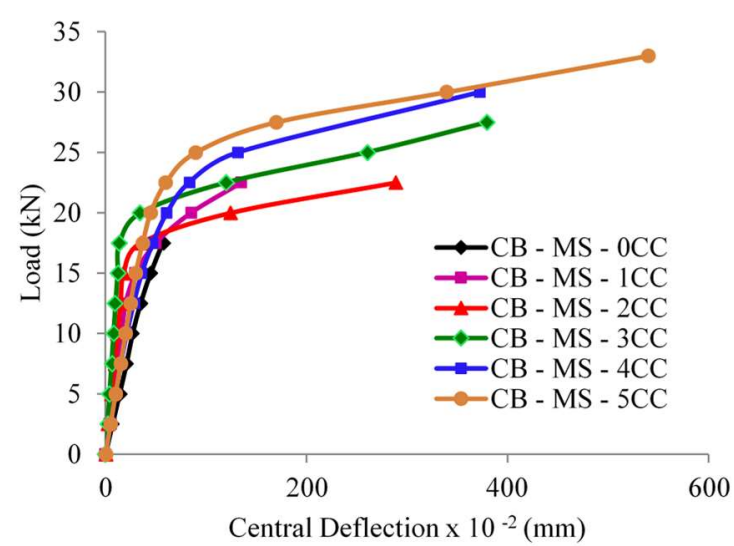

Fig. 6. Load-central deflection of the composite beam with varying numbers of channel connectors

\subsection{Load - strain behaviour}

Figures 7 and 8 show the load-strain plot for the cold-formed steel composite beam and channel shear connectors. The longitudinal strain between the steel and concrete is distributed linearly up to 50 to $60 \%$ of the maximum load-carrying capacity which indicates the composite action in the sections at the initial loading stages. For the higher loads, the strain values are higher due to yielding of the cold-formed steel-channel section at the bottom of the composite beam which is acting as additional reinforcement along with the shear connectors. The maximum strain observed in the composite beam at failure was 0.0005 and for the channel shear connectors, 0.0007 . Sample CB $-\mathrm{MS}-5 \mathrm{CC}$ was able to resist more strain due to the confinement of steel and concrete with shear connectors.

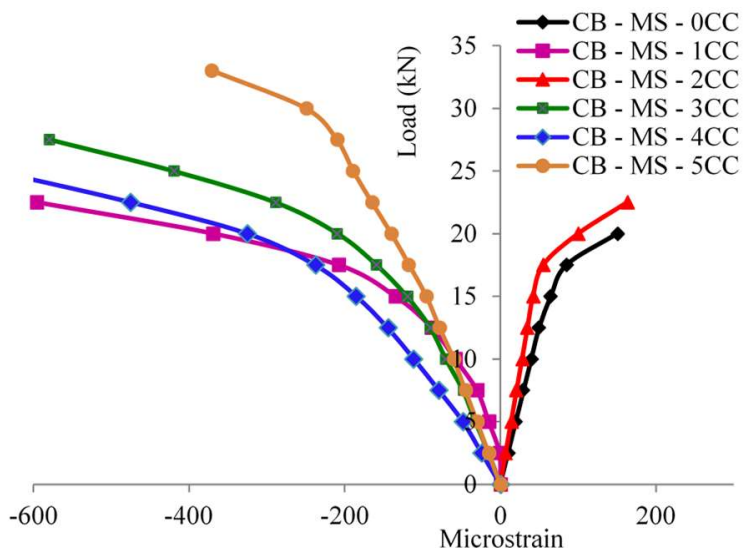

Fig. 7. Load-strain behaviour of the Composite beam 


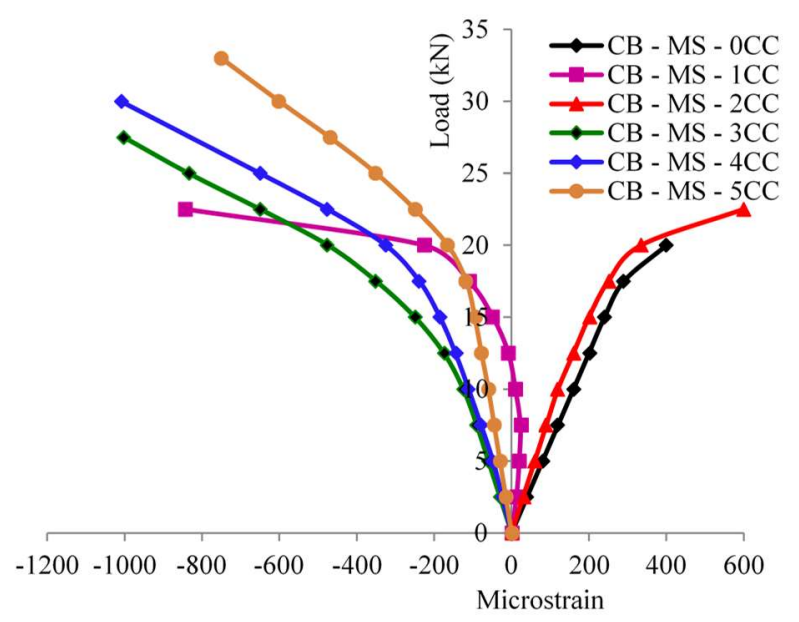

Fig. 8. Load-strain behaviour of the channel shear connectors

\subsection{Load - slip behaviour}

Figure 9 shows the load-slip behaviour between the steel and concrete of the composite beam. From figure 9., it is clear that the slip between the steel and concrete is much lower for the composite beam with five channel connectors. The ductile behaviour was observed in samples $\mathrm{CB}-\mathrm{MS}-4 \mathrm{CC}$ and $\mathrm{CB}-\mathrm{MS}-5 \mathrm{CC}$. Increasing the number of connectors from 1 to 5 increased the overall stiffness by $95 \%$. Table 2 gives the maximum slip, maximum load capacity, and maximum strain observed from all samples.

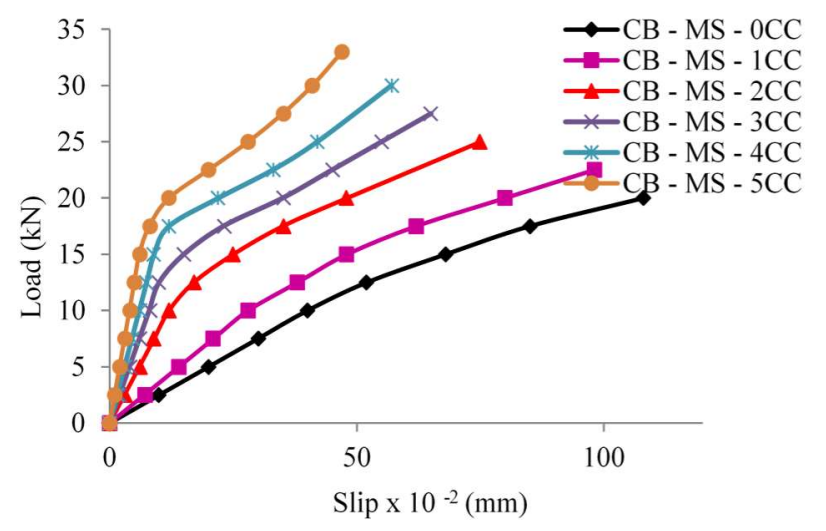

Fig. 9. Load-slip behaviour of the composite beam 
Table 2. Observed experimental slip and strain values of the composite beam

\begin{tabular}{|c|c|c|c|c|c|}
\hline $\begin{array}{c}\text { Sl. } \\
\text { No }\end{array}$ & Sample Name & $\begin{array}{c}\text { Maximum } \\
\text { Load } \\
\text { carrying } \\
\text { capacity } \\
(\mathrm{kN})\end{array}$ & $\begin{array}{c}\text { Maximum } \\
\text { slip between } \\
\text { steel and } \\
\text { concrete } \\
(\mathrm{mm})\end{array}$ & $\begin{array}{c}\text { Maximum } \\
\text { strain in } \\
\text { composite } \\
\text { beam }\end{array}$ & $\begin{array}{c}\text { Maximum } \\
\text { strain in } \\
\text { shear } \\
\text { connector }\end{array}$ \\
\hline 1 & $\mathrm{CB}-\mathrm{MS}-0 \mathrm{CC}$ & 20.0 & 1.08 & 0.000150 & 0.000400 \\
\hline 2 & $\mathrm{CB}-\mathrm{MS}-1 \mathrm{CC}$ & 22.5 & 0.98 & 0.000596 & 0.000842 \\
\hline 3 & $\mathrm{CB}-\mathrm{MS}-2 \mathrm{CC}$ & 25.0 & 0.75 & 0.000163 & 0.000600 \\
\hline 4 & $\mathrm{CB}-\mathrm{MS}-3 \mathrm{CC}$ & 27.5 & 0.65 & 0.000579 & 0.001002 \\
\hline 5 & $\mathrm{CB}-\mathrm{MS}-4 \mathrm{CC}$ & 30.0 & 0.57 & 0.001009 & 0.000849 \\
\hline 6 & $\mathrm{CB}-\mathrm{MS}-5 \mathrm{CC}$ & 32.5 & 0.47 & 0.000370 & 0.000750 \\
\hline
\end{tabular}

\section{ANALYTICAL STUDY}

All the composite beams were analysed using ANSYS software in order to compare the maximum central deflection between the experimental and analytical results. SOLID 186 and SOLID 65 were used from the element library of ANSYS. The material inputs are $2 \times 10^{5} \mathrm{~N} / \mathrm{mm}^{2}$ and $25000 \mathrm{~N} / \mathrm{mm}^{2}$ for steel and concrete, respectively. Figure 10 and 11 shows the mesh model and deformed shape of the composite beam.

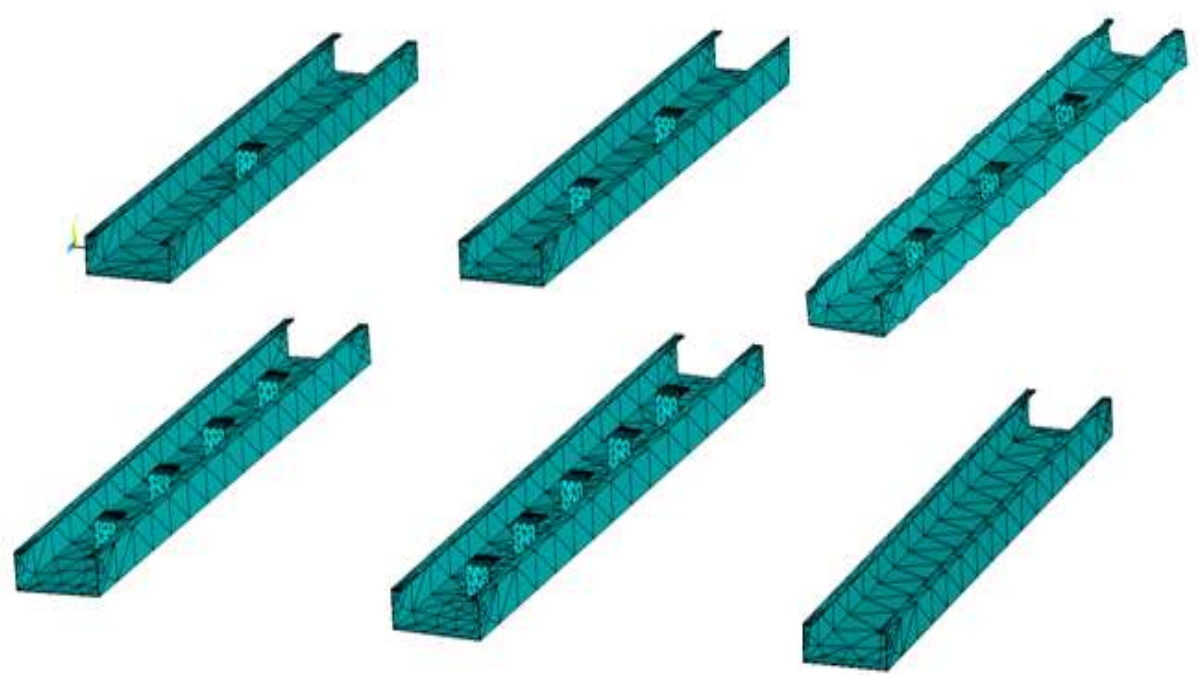

Fig. 10. ANSYS mesh model of the samples with connectors 


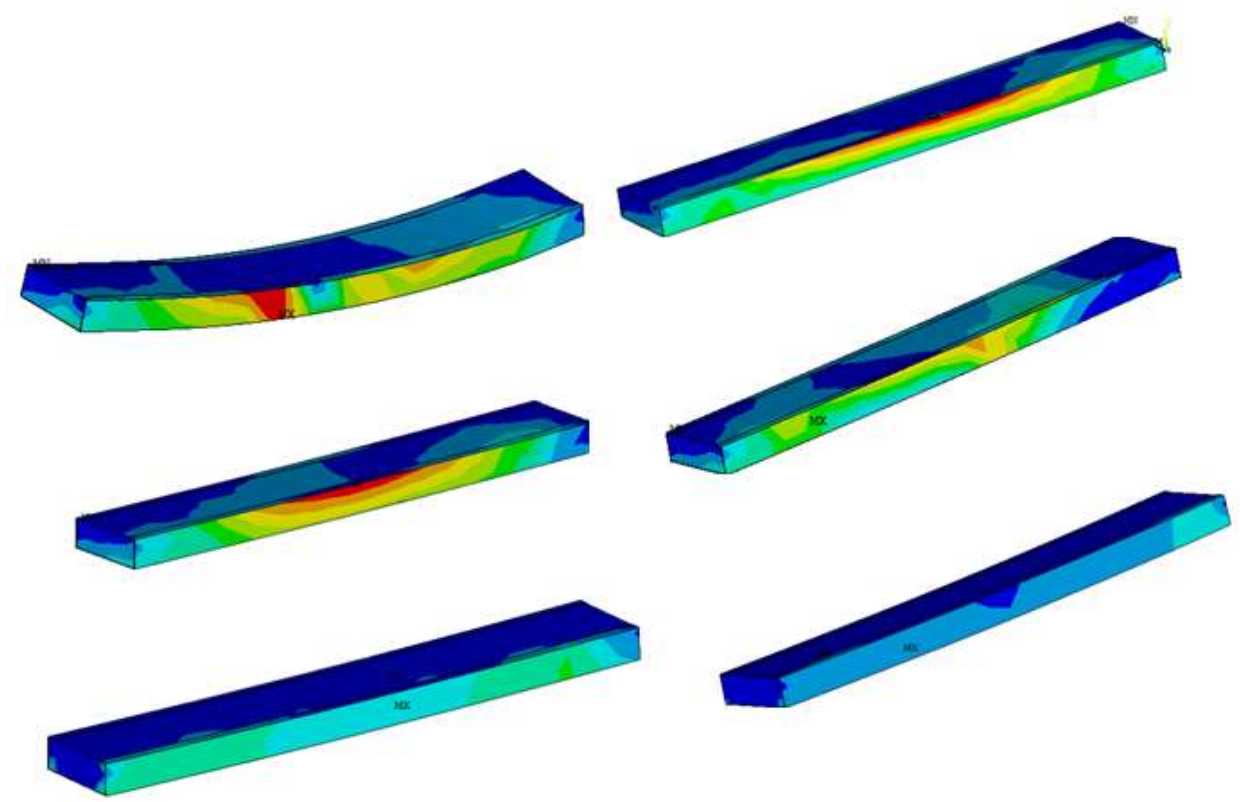

Fig. 11. Deformed shape of the composite beam

Table 2 gives a comparison between the experimental and analytical results where it was found that the ratio between the experimental deflection and analytical deflection ranges from 1.04 to 1.21 .

Table 2. Comparison between Experimental and Analytical results of the composite beam

\begin{tabular}{|c|c|c|c|c|c|c|}
\hline $\begin{array}{c}\text { S1. } \\
\text { No }\end{array}$ & $\begin{array}{c}\text { Specimen } \\
\text { Name }\end{array}$ & $\begin{array}{c}\text { Maximum } \\
\text { Load } \\
\text { carrying } \\
\text { capacity } \\
(\mathrm{kN})\end{array}$ & $\begin{array}{c}\text { Maximum } \\
\text { central } \\
\text { deflection } \\
\Delta_{\text {exp }} \\
(\mathrm{mm})\end{array}$ & $\begin{array}{c}\text { Maximu } \\
\text { m central } \\
\text { deflection } \\
\Delta_{\text {Anal }} \\
(\mathrm{mm})\end{array}$ & $\begin{array}{c}\Delta_{\text {exp }} / \\
\Delta_{\text {Anal }}\end{array}$ & $\begin{array}{c}\text { Ductility } \\
\text { Factor } \\
\mu\end{array}$ \\
\hline 1 & $\mathrm{CB}-\mathrm{MS}-0 \mathrm{CC}$ & 20.0 & 0.57 & 0.519 & 1.10 & 1.05 \\
\hline 2 & $\mathrm{CB}-\mathrm{MS}-1 \mathrm{CC}$ & 22.5 & 1.23 & 1.033 & 1.19 & 4.05 \\
\hline 3 & $\mathrm{CB}-\mathrm{MS}-2 \mathrm{CC}$ & 25.0 & 2.89 & 2.791 & 1.04 & 9.29 \\
\hline 4 & $\mathrm{CB}-\mathrm{MS}-3 \mathrm{CC}$ & 27.5 & 3.80 & 3.151 & 1.21 & 11.28 \\
\hline 5 & $\mathrm{CB}-\mathrm{MS}-4 \mathrm{CC}$ & 30.0 & 4.92 & 4.602 & 1.07 & 11.71 \\
\hline 6 & $\mathrm{CB}-\mathrm{MS}-5 \mathrm{CC}$ & 32.5 & 7.20 & 6.872 & 1.05 & 13.85 \\
\hline
\end{tabular}




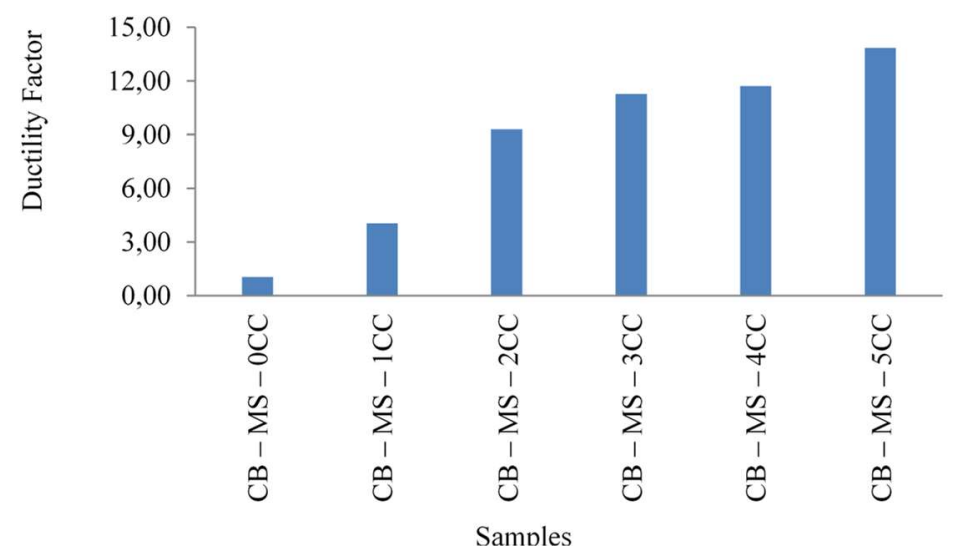

Fig. 13. Ductility factor of the composite beam

From figure 14, it is observed that the experimental and analytical deflection of the cold-formed steel-composite beam is almost the same except for the sample with three channel connectors. The maximum central deflection of CB - MS $3 \mathrm{CC}$ was $20 \%$ less when compared to an experimental deflection of $3.8 \mathrm{~mm}$. This may be due to the better bonding of the connectors with concrete which produced better composite action between steel and concrete.

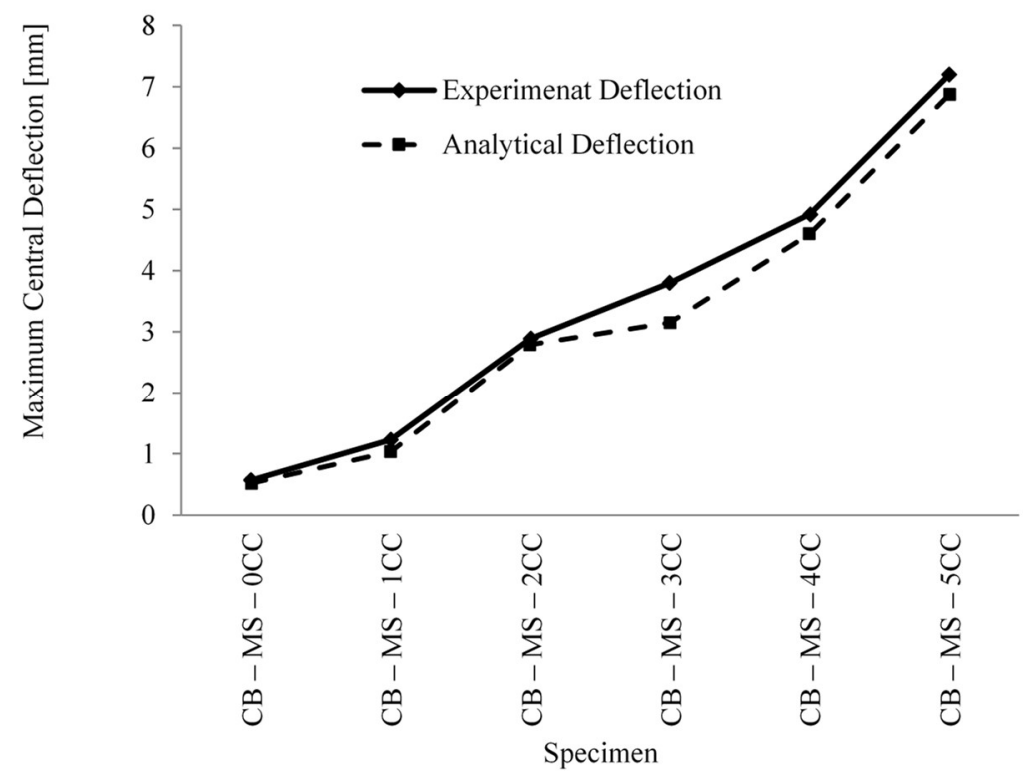

Fig. 14. Comparison between the experimental and analytical maximum deflection 


\section{CONCLUSIONS}

The following conclusions can be drawn from the study into the behaviour of cold-formed steel-concrete composite beams with varying numbers of connectors:

1. The cold-formed steel sample with five channel connector's showed better performance in terms of maximum load-carrying capacity, reduced slip between steel and concrete, and was able to resist more deformation at the centre.

2. The failure of the samples was due to the formation of cracks on the concrete surface under the loading point as well as some cracks which initiated from the location of the channel connectors due to the failure of the shear connectors in the tension zone of the cold-formed steel-concrete composite beam.

3. The load-carrying capacity of the composite beam improved by $60 \%$ with increasing number of channel connectors from 0 to 5 .

4. The overall percentage increase in the stiffness of the composite beam is about $95 \%$ and the slip between steel and concrete is minimal for the specimen $\mathrm{CB}$ $-\mathrm{MS}-5 \mathrm{CC}$.

5. The ductility factor, which is the ratio between the deflection at yield point and the deflection at ultimate point, varies from 1.05 to 13.85 with the increase in the number of connectors from 0 to 5 .

6. The difference in the results between the experimental and analytical tests was in the ratio of 1.04 to 1.27 which is agreeable and gives confidence for further use of the analytical model in predicting the results.

\section{CONFLICT OF INTEREST STATEMENT}

The author declares no conflict of interest in the publication of this article.

\section{REFERENCES}

1. Kottiswaran, N and Sundararajan, R 2005. Behaviour of Thin-Walled ColdFormed Steel-Concrete Composite Beams. Proceedings of National SeminarREDECON, 373-381.

2. Eray Baran and Cem Topkaya 2012. An experimental study on channel type shear connectors. J. of Cons. Steel Research, 74, 108-117.

3. Adil Dar, M, Subramanian Narayanan, M, Anbarasu, Abdul Rashid Dar and James, BP Lim 2018. Structural performance of cold-formed steel-composite beams. Steel and Compo. Str. 27, 545-554. 
4. Manikandan, P, Sukumar, S and Balaji, TU 2014. Effective shaping of ColdFormed Thin-Walled Built-up Beams in Pure Bending. Arabian J. for Sci. and Eng. 39, 6043-6054.

5. Wehbe, N, Bahmani, P and Wehbe, A 2013. Behaviour of Concrete/ColdFormed Steel-Composite Beams: Experimental Development of a Novel Structural System. Int. J. Cont. Stru. Mat.1, 51-59.

6. Anis Saggaff, Mahmood Md. Tahir, Mohammadamin Azimi, and Alhajri, TM 2017. Structural aspects of cold-formed steel section designed as a U-shape composite beam. AIP Conference Proceedings. 1903, 1-11.

7. Sangeetha, P and Senthil, R 2017. A study on ultimate behaviour of composite space trusses, KSCE J. of Civil Eng. 21, 950-954.

8. Sangeetha, P and Ashwin, Muthuraman, R 2018. Performance of steelconcrete sandwich beam with varying shear connectors, Indian Journal of Science and Technology, Vol. 11, No. 34, 2018, pp.1-7.

9. Sangeetha, P 2017. Parametric study on the stiffness and energy absorption capacity of composite space truss. Int. J. of Adv. Appl. Sci. 4, 1-5.

10. Sangeetha, P and Senthil, R 2018. Experimental Study on the Service Load Behaviour of the Composite Space Truss. J. of Stru. Eng. 44,632-636.

Editor received the manuscript: 24.08.2019 